\title{
Adipose Tissue Dysfunction: Clinical Relevance and Diagnostic Possibilities
}

\author{
Authors \\ I. M. Schrover ${ }^{1}$, W. Spiering ${ }^{1}$, T. Leiner ${ }^{2}$, F. L. J. Visseren \\ Affiliations \\ Department of Vascular Medicine, University Medical Center Utrecht, Utrecht, The Netherlands \\ 2Department of Radiology, University Medical Center Utrecht, Utrecht, The Netherlands
}

Key words
adipose tissue
dysfunction
diagnosis
metabolic syndrome

received 01.08 .2015

accepted 11.02.2016

Bibliography

DOI http://dx.doi.org/

10.1055/s-0042-103243

Horm Metab Res 2016;

48: $213-225$

(c) Georg Thieme Verlag KG

Stuttgart · New York

ISSN 0018-5043

Correspondence

Prof. F. L. J. Visseren

Department of Vascular

Medicine

P. O. Box 85500

3508 GA Utrecht

The Netherlands

Tel.: + 31/88/7555 161

Fax: $+31 / 30 / 2523741$

F.L.J.Visseren@umcutrecht.nl

\section{Abstract}

$\nabla$

Adipose tissue dysfunction is defined as an imbalance between pro- and anti-inflammatory adipokines, causing insulin resistance, systemic low-grade inflammation, hypercoagulability, and elevated blood pressure. These can lead to cardiovascular disease and diabetes mellitus type 2 . Although quantity of adipose tissue is an important determinant of adipose tissue dysfunction, it can be diagnosed in both obese and lean individuals. This implies that not only quantity of adipose

\begin{tabular}{ll}
\hline Abbreviations \\
BMI: & Body mass index \\
DM2: & Diabetes mellitus type 2 \\
ATD: & Adipose tissue dysfunction \\
FFA: & Free fatty acids \\
TNF- $\alpha$ : & Tumor necrosis factor alpha \\
IL-6: & Interleukin 6 \\
PAI-1: & Plasminogen activator inhibitor 1 \\
WC: & Waist circumference \\
IL-8: & Interleukin 8 \\
IL-18: & Interleukin 18 \\
VAT: & Visceral adipose tissue \\
CT: & Computed tomography \\
MRI: & Magnetic resonance imaging \\
SAT: & Subcutaneous adipose tissue \\
RBP-4: & Retinol binding protein 4 \\
TG: & Triglycerides \\
PUFA: & Poly unsaturated fatty acids \\
TUFA: & Total unsaturated fatty acids \\
HOMA-IR: & Homeostatic model of \\
& assessment-insulin resistance \\
SFRP-5: & Secreted frizzled related protein 5 \\
HGF: & Hepatic growth factor \\
IP-10: & Interferon gamma induced protein \\
MCP-1: & 10 \\
& Monocyte chemo attractant \\
ELISA: & protein 1 \\
& Enzyme linked immunosorbent assay \\
&
\end{tabular}

tissue should be used as a measure for adipose tissue dysfunction. Instead, focus should be on measuring quality of adipose tissue, which can be done with diagnostic modalities ranging from anthropometric measurements to tissue biopsies and advanced imaging techniques. In daily clinical practice, high quantity of visceral adipose tissue (reflected in high waist circumference or adipose tissue imaging), insulin resistance, or presence of the metabolic syndrome are easy and low-cost diagnostic modalities to evaluate presence or absence of adipose tissue dysfunction.

\section{Introduction}

Worldwide, an estimated 1 billion people are overweight (defined as a BMI $>25 \mathrm{~kg} / \mathrm{m}^{2}$ ). Another 500 million are obese $\left(\mathrm{BMI}>30 \mathrm{~kg} / \mathrm{m}^{2}\right)$ [1]. A BMI above $25 \mathrm{~kg} / \mathrm{m}^{2}$ is associated with a $30 \%$ increase in overall mortality, a $40 \%$ increase in vascular mortality, and a $120 \%$ increase in mortality due to complications of diabetes as compared to a $\mathrm{BMI} \leq 25 \mathrm{~kg} / \mathrm{m}^{2}$. It is estimated that 1 in every 7 cases of cardiovascular disease is attributable to overweight and 8 in every 10 cases of incident type 2 diabetes mellitus (DM2) [2,3]. Moreover, a high BMI is associated with an increased incidence of multiple cancer types [4,5]. On the other hand, BMI is an imperfect measure to estimate the contribution of adiposity to future disease risk and mortality [6], since not the quantity of adipose tissue itself is the causal factor in the occurrence of cardiovascular diseases, DM2, and cancer, but the metabolic consequences of adiposity as a result of adipose tissue dysfunction (ATD). Insulin resistance, hypertriglyceridemia, low HDL-cholesterol, hypertension, hypercoagulability, and low-grade inflammation are metabolic risk factors related to ATD [7-9]. Obese patients who are metabolically healthy do not exhibit unfavorable metabolic changes [10], are not insulin resistant [11], and have a low risk of 
developing cardiovascular diseases [9], indicating that not only adipose tissue quantity matters, but also adipose tissue function. This concept of ATD is signified by patients who are metabolically obese despite a normal weight $[12,13]$. These patients have an increased risk for DM2 and cardiovascular disease. The diagnosis or identification of ATD may therefore be of clinical relevance serving as a tool for stratifying risk for cardiovascular diseases, DM2, and even cancer, and may guide preventive treatment with both medication and lifestyle interventions [14]. ATD may even serve as a direct treatment target [15]. This would be in contrast to a more general approach with the focus on adipose tissue quantity reflected by overweight and obesity as measured with BMI.

In this review, we evaluate current evidence of different options for diagnosing ATD, ranging from anthropometric measurements to tissue biopsies and advanced imaging techniques. In the absence of the possibility of a direct diagnosis of ATD, we use consequences of ATD as surrogate indication of the presence of ATD.

\section{Adipose Tissue Dysfunction \\ $\nabla$}

When total energy intake exceeds energy expenditure, this excess energy is stored in adipose tissue leading to enlargement of adipocytes. As a consequence, hypertrophic adipocytes produce chemotactic adipokines, which attract macrophages to adipose tissue $[16,17]$. Inflamed adipose tissue is able to produce large amounts of free fatty acids (FFA) and pro-inflammatory adipokines, such as tumor necrosis factor alpha (TNF- $\alpha$ ), leptin, chemerin, and interleukin-6 (IL-6), whereas the production of the protective adipokine adiponectin is reduced [18-20]. ATD refers to the imbalanced production and release of pro- and anti-inflammatory adipokines. The systemic metabolic consequences of ATD include systemic low-grade inflammation, hypercoagulability, elevated blood pressure, dyslipidemia, and insulin resistance. Insulin resistance occurs as a result of interference with the intracellular insulin signaling cascade by TNF- $\alpha$ and FFA in various target organs [18]. Part of these systemic metabolic consequences are clustered in the metabolic syndrome, which is defined as the presence of $\geq 3$ of the following items: waist circumference $>102 \mathrm{~cm}$ (men) or $>88 \mathrm{~cm}$ (women), triglycerides $\geq 1.7 \mathrm{mmol} / \mathrm{l}, \quad \mathrm{HDL}-\mathrm{c}<1.03 \mathrm{mmol} / \mathrm{l}$ (men) or $<1.29 \mathrm{mmol} / \mathrm{l}$ (women) or use of lipid-lowering medication, systolic blood pressure $\geq 130 \mathrm{mmHg}$ and/or diastolic blood pressure $\geq 85 \mathrm{mmHg}$ or use of blood pressure-lowering medication, fasting plasma glucose $\geq 5.6 \mathrm{mmol} / \mathrm{l}$ or use of glucose-lowering medication $[21,22]$.

Although obesity is the most important driver of ATD development, not all, but approximately $80 \%$ of obese individuals become insulin resistant [10]. Moreover, $10-40 \%$ of nonobese individuals develop insulin resistance $[12,13,23]$, indicating that other factors are also involved in the development of ATD. Both exogenous factors such as physical inactivity [24,25] and the dietary intake of saturated fat $[26,27]$, as well as endogenous susceptibility such as a low birth-weight $[28,29]$, genetic predisposition [30,31], and an overactive sympathetic nervous system $[32,33]$ may all contribute to the development of ATD.

Dysfunctional adipose tissue contributes to the development of diabetes mellitus by causing insulin resistance [34] and through cytotoxic effects of pro-inflammatory adipokines and free fatty acids on pancreatic beta cells, leading to diminished insulin pro- duction ( $\bullet$ Fig. 1) [35]. There are various pathophysiological mechanisms linking ATD to atherosclerotic vascular diseases, including systemic low-grade inflammation by production of IL- 6 by adipose tissue, a procoagulant state as a result of plasminogen activator inhibitor-1 (PAI-1) production, direct effects of adipokines on the endothelium, activation of the renin-angiotensin-aldosterone system by adipose tissue production of angiotensinogen, and activation of the sympathetic nervous system possibly due to high levels of insulin, leptin, and angiotensin II centrally exerting a sympatho-exitatory response [36-38]. Diagnosing ATD may identify patients at high risk for the development of diabetes mellitus and vascular diseases and may guide preventive measures in an early stage. Potential diagnostic tools for identifying patients with ATD are outlined below. The diagnostic value will be evaluated in the context of pathophysiological characteristics (morphologic changes in adipose tissue and plasma adipokine concentrations), as well as to clinical outcome of ATD (metabolic syndrome, DM2, and cardiovascular diseases).

\section{Anthropometric Measurements}

$\nabla$

There is a strong relation between the quantity of adipose tissue and ATD [39-41]. Adipose tissue quantity, as measured with either BMI or waist circumference (WC) is related to plasma concentrations of adipokines, to morphologic characteristics of adipose tissue, and to the development of the metabolic syndrome, DM2, and vascular diseases [39-41]. Pro-inflammatory adipokines (IL-6, IL-8, IL-18, TNF- $\alpha$, PAI1, and leptin) are known to be positively correlated with both BMI and WC [42-45], whereas the anti-inflammatory adiponectin is negatively correlated with BMI and WC [42-46]. In subcutaneous adipose tissue biopsies, IL-6 and IL-8 expression are associated with waist circumference [47]. Moreover, both BMI and WC are associated with the amount of macrophages in both subcutaneous and omental adipose tissue [48], and with adipocyte size [48].

The relation between adipose tissue quantity, measured with BMI and WC, and metabolic disturbances is illustrated by the fact that only $5 \%$ of normal weight individuals $\left(\mathrm{BMI}<25 \mathrm{~kg} / \mathrm{m}^{2}\right.$ ) fulfill the criteria for the metabolic syndrome $[11,39,49,50]$, compared to $20 \%$ in subjects with a BMI $25-30 \mathrm{~kg} / \mathrm{m}^{2}$ and $50 \%$ in obese $\left(\mathrm{BMI}>30 \mathrm{~kg} / \mathrm{m}^{2}\right)$ individuals $[11,39,49,50]$. Accordingly, the prevalence of insulin resistance increases when BMI is higher, ranging from $6 \%$ in normal weight subjects $(\mathrm{BMI}<25 \mathrm{~kg}$ / $\mathrm{m}^{2}$ ) to $60-80 \%$ when $\mathrm{BMI}$ is $>35 \mathrm{~kg} / \mathrm{m}^{2}[11,39,51,52]$.

Waist circumference reflects visceral adipose tissue (VAT) rather than general adiposity [53-55] and has a stronger relation with the metabolic syndrome and insulin resistance than BMI [3941]. Within strata of BMI, a high WC (i.e., $>88 \mathrm{~cm}$ in women and $>102 \mathrm{~cm}$ in men) doubles the risk of metabolic syndrome compared to persons in the same BMI category with a normal WC [39]. Moreover, the risk for cardiovascular morbidity and mortality is better reflected by WC than by BMI [40]. This is in line with the observation that ATD is most prominently related to the quantity of VAT $[40,41,56]$.

\section{Clinical recommendation}

Based on these facts we recommend the use of waist circumference rather than BMI in the evaluation of possible ATD. 


\section{Imaging of Adipose Tissue}

$\nabla$

As described in Section 3, ATD is strongly related to the quantity of adipose tissue and especially to the quantity of VAT $[40,41,55]$. Therefore, precise quantitative measurement of (visceral) adipose tissue is important in the diagnosis of ATD. Several imaging modalities are capable of measuring adipose tissue depots in different anatomical locations. Ultrasonography, computed tomography $(\mathrm{CT})$ as well magnetic resonance imaging (MRI) have all been used for this purpose [57-59]. In addition, MRI is well-suited to probe adipose tissue (dys)function using MR spectroscopy [60].

\section{Quantitative measurement of visceral adipose tissue (VAT) and subcutaneous adipose tissue (SAT) with imaging modalities}

Ultrasound measurements of adipose tissue are obtained by measuring the distance between the skin and the linea alba in $\mathrm{cm}$ (SAT) and the distance between the peritoneum and the lumbal vertebrae in $\mathrm{cm}$ for VAT [61,62]. As such these measurements are a proxy for the total amount of adipose tissue. CT or MRI measurements of adipose tissue are considered the reference standard. Adipose tissue can be measured in a cross-sectional fashion, for example, at the level of the L4-L5 vertebrae, where the amount in $\mathrm{cm}^{2}$ is computed, or as the total volume of adipose tissue in the abdomen using planimetric software [59,61-63]. In most studies, quantification relies on manual segmentation, but semi- and fully-automated methods are under

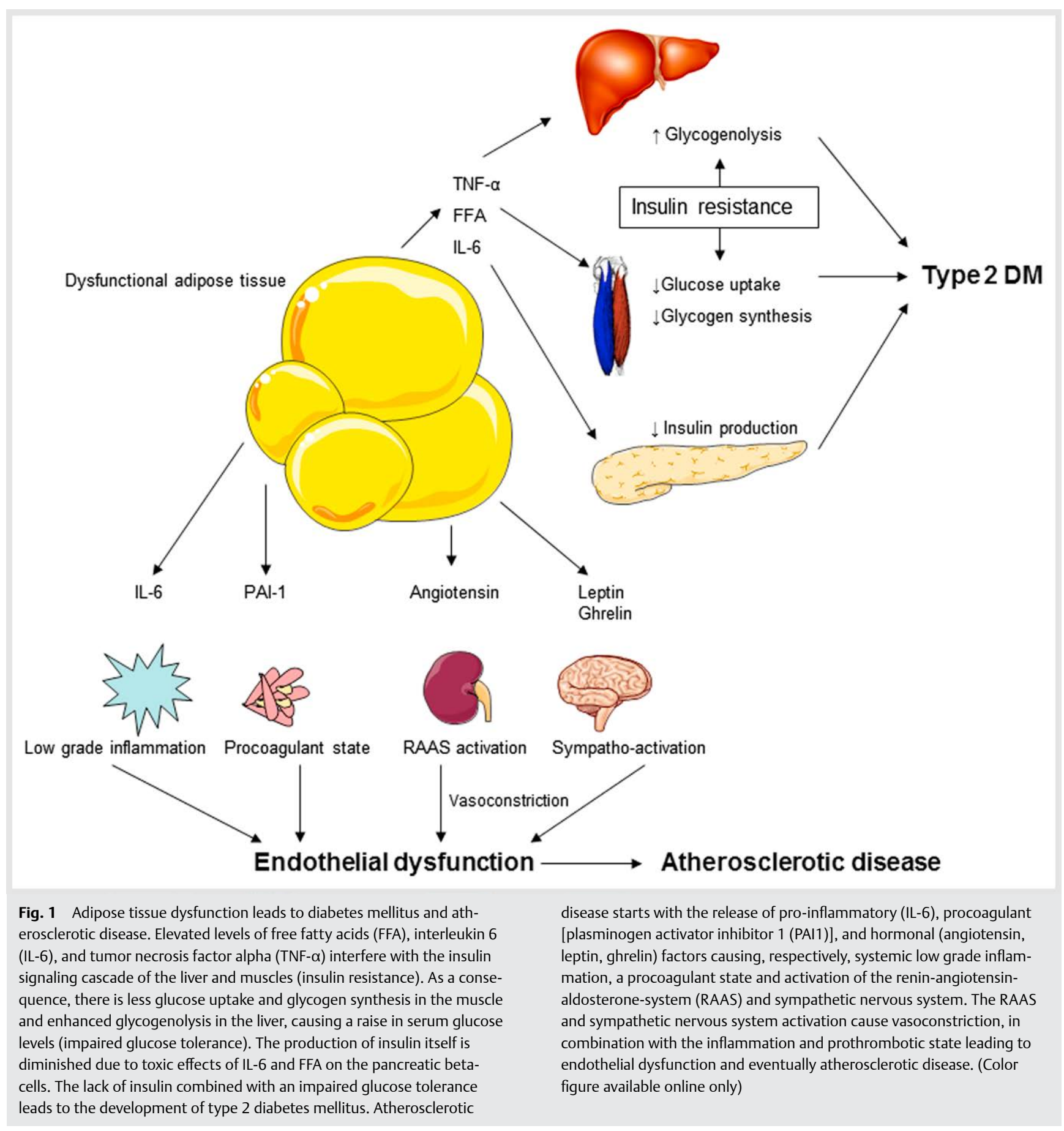


development $[64,65]$. Ultrasonographic measurements of adipose tissue are highly correlated to CT or MRI measurements of adipose tissue, with Pearson correlation coefficients of 0.64$0.81[61,62]$.

Perhaps the most interesting and promising family of techniques to quantify the amount of adipose tissue in different body regions are based on multi-echo 3-dimensional chemical-shiftencoding water-fat imaging, also known as 'Dixon' methods. These methods encode both spatial position and chemical shift during the acquisition and subsequently estimate the contributions of water and fat to the measured signal in each voxel [66]. Using these methods, adipose tissue and water can be automatically separated per scanned voxel, allowing direct imaged based water and adipose tissue quantitation [67].

Examples of ultrasound, CT, MRI and Dixon adipose tissue measurements are provided in $\odot$ Figs. 2,3.

The quantity of VAT, as measured with ultrasound, CT, or MRI, is positively related to plasma concentrations of the pro-inflammatory adipokines IL-6, TNF- $\alpha$, leptin, and retinol binding protein 4 (RBP-4) [68-72]. For SAT, this relation is considerably attenuated or nonexistent [68-72]. Adiponectin levels are negatively correlated to both VAT and SAT [69,72-75], although the correlation with VAT is consistently stronger than the correlation with SAT [69, 72,74].

Volumetric CT, MRI, and ultrasound measurements of VAT are consistently correlated more strongly to cardiometabolic risk factors (hypertension, impaired fasting glucose) and the development of the metabolic syndrome, DM2 and (subclinical) atherosclerotic disease compared to SAT [56,76-78]. About $20 \%$ of men and $10 \%$ of women have a high amount of VAT $\left(>90^{\text {th }}\right.$ percentile healthy referent sample) at CT-scanning, despite having a normal waist circumference [79]. These persons have a $20 \%$ higher risk of developing the metabolic syndrome compared to subjects with an elevated waist circumference, but with a low amount of VAT on CT-scan $[79,80]$.

\section{Functional imaging of adipose tissue with ${ }^{1} \mathrm{H}$ magnetic resonance spectroscopy}

A promising MR imaging based technique is proton magnetic resonance spectroscopy $\left({ }^{1} \mathrm{H}\right.$ MRS $)$. With ${ }^{1} \mathrm{H}$ MR-spectroscopy it is possible to quantify localized lipid content in relation to the amount of water. Chemical characteristics of water and fat and their reaction to magnetic forces in the MRI-scanner are used to obtain a visual spectrum of metabolites [81]. ${ }^{1} \mathrm{H}$ MR-spectroscopy has been used to quantify free fatty acids, such as triglycerides (TG), poly-unsaturated fatty acids (PUFA), total unsaturated fatty acids (TUFA), and saturated fatty acids (SFA), in the myocardium, liver, breast, muscle, bone marrow, and SAT [82-86]. In general, a reduction in saturated fatty acid ingestion reduces the risk of a cardiovascular event, with $17 \%$, probably via reduction of LDL-cholesterol levels. There is no effect of reducing saturated fatty acids on cardiovascular or all-cause mortality. Patients with DM2 have more unsaturated fatty acids in the liver compared to patients without DM2, influencing insulin resistance as reflected in higher glucose and HOMA-IR (Homeostatic Model Assessment - Insulin Resistance) levels [86]. Exercise reduces intrahepatic triglyceride content up to $50 \%$, especially in males [87], even in the absence of changes in total body fat or VAT [88]. Low hepatic triglyceride content is related to a lower risk of developing nonalcoholic fatty liver disease, a condition frequently seen in obese subjects [87].
Hepatic triglyceride content increases from 2.0 to $4.3 \%$ in healthy men after a 3-day high fat high energy diet, consisting of $800 \mathrm{ml}$ whipped cream added to a normal diet of about $2100 \mathrm{kcal} /$ day [85]. Contrary, a 3-day low fat low energy diet, consisting of less than $500 \mathrm{kcal} /$ day reduced intrahepatic triglyceride content by $4 \%$ in patients with DM2 [89]. These observations stress the shortterm and flexible reactions of different (nonadipose) tissues to diet and exercise interventions as measured with ${ }^{1} \mathrm{H}$ MRS.

Only limited data on lipid composition and reactions to interventions concerning (abdominal) adipose tissue are available. Quantification of triglyceride content of SAT with ${ }^{1} \mathrm{H}$ MRS at 1.5 Tesla revealed that there was no correlation with serum lipid concentrations $[82,90]$. The amount of unsaturated fatty acids in abdominal adipose tissue correlated negatively with the amount of SAT and positively with the amount of VAT [90]. PUFA/TUFA and PUFA/TG ratios, as measured with MR spectroscopy, are higher in persons with the metabolic syndrome, especially in the omental adipose tissue depot, compared to subjects without the metabolic syndrome [60]. MR-spectroscopy is a noninvasive technique and a direct way of measuring metabolic characteristics of abdominal adipose tissue, which makes this technique a promising diagnostic tool for the identification of ATD.

\section{Clinical recommendation}

Although both CT and MRI measurements of adipose tissue provide detailed information of VAT and SAT, and (in the case of MRS) are feasible in research, implementing these modalities in clinical practice might be difficult due to both costs and logistics. Ultrasound measurements might be a useful alternative.

\section{Insulin Resistance and Metabolic Syndrome $\nabla$}

Insulin resistance is a condition with decreased sensitivity or responsiveness to the metabolic actions of insulin, caused by interference of the intracellular insulin signaling cascade by TNF- $\alpha$ and FFA [18]. Insulin resistance causes reduced capacity of adipocytes to store FFAs, causing lipid accumulation in muscles, pancreas, and liver contributing to insulin resistance. As a result, glucose clearance is diminished and glucose production enhanced in the liver, leading to a hyperinsulinemic state [91]. Insulin resistance or sensitivity can be assessed using several mathematical rules, such as the HOMA-IR or revised Quicki methods. The revised Quicki method correlates better with the reference standard [92] (euglycemic clamp) but necessitates more laboratory values (such as nonesterified fatty acids) than the HOMA-IR (which uses insulin and glucose levels). However, both methods have been used in clinical research regarding adipokines.

\section{Insulin resistance related to adipokines and morphology of adipose tissue}

Adiponectin is consistently negatively correlated to insulin resistance [93-97] whereas leptin is consistently positively correlated [96-99]. Together, adiponectin and leptin levels explained $38 \%$ of HOMA-IR variance in a group of elderly individuals [97]. Resistin [99] and TNF- $\alpha$ [100] were also found to be positively correlated to HOMA-IR. For IL-6 no relation was seen with insulin resistance in nonobese diabetic patients [96], but in patients with a BMI $>27 \mathrm{~kg} / \mathrm{m}^{2}$ a relation between IL- 6 and insulin resistance exists $[101,102]$, suggesting a role for the quantity of adipose tissue. In insulin resistant mice, larger adipocytes and more mac- 

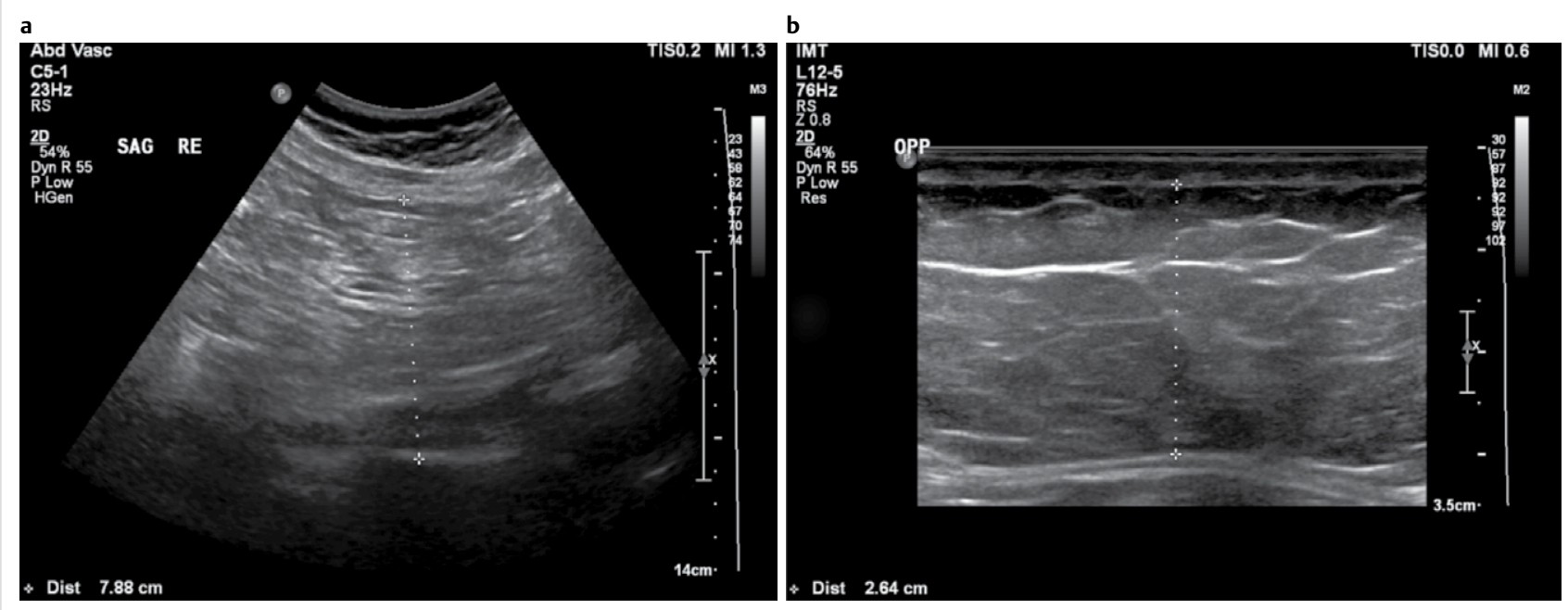

Fig. 2 Ultrasonography is well suited for distinguishing subcutaneous and intra-abdominal adipose tissue. Although intra-abdominal adipose tissue is not visualized directly with ultrasonography, the anteroposterior distance between the peritoneum behind the rectus musculature and the vertebral column (panel a) can serve as reasonable proxy measure for the amount of adipose tissue. Measurements are performed with a $5 \mathrm{MHz}$ transducer. Subcutaneous adipose tissue is measured by measuring anteroposterior distance between the skin and the linea alba between the rectus abdominis muscle with a 12.5 MHz transducer (panel b).

rophage infiltration were seen than in mice without insulin resistance [103]. In patients undergoing bariatric surgery or cholecystectomy, the presence of foam cells (macrophages loaded with lipids) in VAT was positively correlated to insulin concentrations, whereas there was no correlation between foam cells in the SAT and insulin concentrations [104]. Therefore, measuring insulin resistance is a diagnostic tool for identifying ATD.

Insulin resistance related to metabolic syndrome, DM2, and cardiovascular disease

Yearly, 5-10\% of people with insulin resistance develop overt diabetes [105] and the presence of insulin resistance and the metabolic syndrome are highly correlated [106], with about $60 \%$ of patients with insulin resistance also fulfilling the criteria for metabolic syndrome $[107,108]$. In a large meta-analysis it was shown that there is a $46 \%$ increased risk of coronary heart disease per 1 standard deviation increase of HOMA-IR [109], the risk for all-cause mortality is $64 \%$ increased in patients with a HOMA-IR $>2.8$ as compared to patients with a HOMA-IR $<1.4$ [110].

\section{Metabolic syndrome related to adipokines and morphology of adipose tissue}

Since almost all characteristics of the metabolic syndrome can be regarded as systemic metabolic consequences of ATD, it is not surprising that there are strong associations of the metabolic syndrome with elevated plasma levels of pro-inflammatory adipokines (leptin, TNF- $\alpha$, IL-6) and lower adiponectin levels $[45,94,98,111,112]$. Moreover, in SAT biopsies of subjects with metabolic syndrome the macrophage content is higher compared to subjects without the metabolic syndrome, illustrating the relation between morphologic changes in adipose tissue, ATD, and clinical features [113].
Metabolic syndrome related to DM2 and cardiovascular diseases

Since characteristics of the metabolic syndrome are systemic consequences of ATD, consequently, associations between metabolic syndrome and DM2 and cardiovascular diseases originate in the presence of ATD. There is a significant relationship between the metabolic syndrome and the occurrence of incident coronary heart disease, with a 60-200\% higher risk for subjects with compared to subjects without the metabolic syndrome $[114,115]$. Also, both cardiovascular (80\% higher risk) and overall (40\% higher risk) mortality are higher in subjects with the metabolic syndrome compared to subjects without the metabolic syndrome $[115,116]$. The presence of the metabolic syndrome constitutes an increased risk of $137 \%$ of developing type 2 diabetes, independent of glucose levels [117].

\section{Clinical recommendation}

Determining a HOMA level and the presence or absence of metabolic syndrome is recommended.

\section{Plasma Concentrations of Adipokines as a Surrogate of ATD}

Adipokines are produced by adipose tissue and secreted into the systemic circulation and can be measured in peripheral venous blood samples. The plasma concentrations of various adipokines vary widely between patients and patient groups and can be influenced as a result of interventions such as weight loss and medication [118-125]. Elevated levels of pro-inflammatory adipokines and decreased levels of anti-inflammatory adipokines are key features of ATD.

\section{Pro-inflammatory adipokines}

The adipokine leptin is the product of the obese-gene and is known for its inhibitory effect on the sense of appetite [126,127]. The production of leptin by adipose tissue is stimulated by pro- 

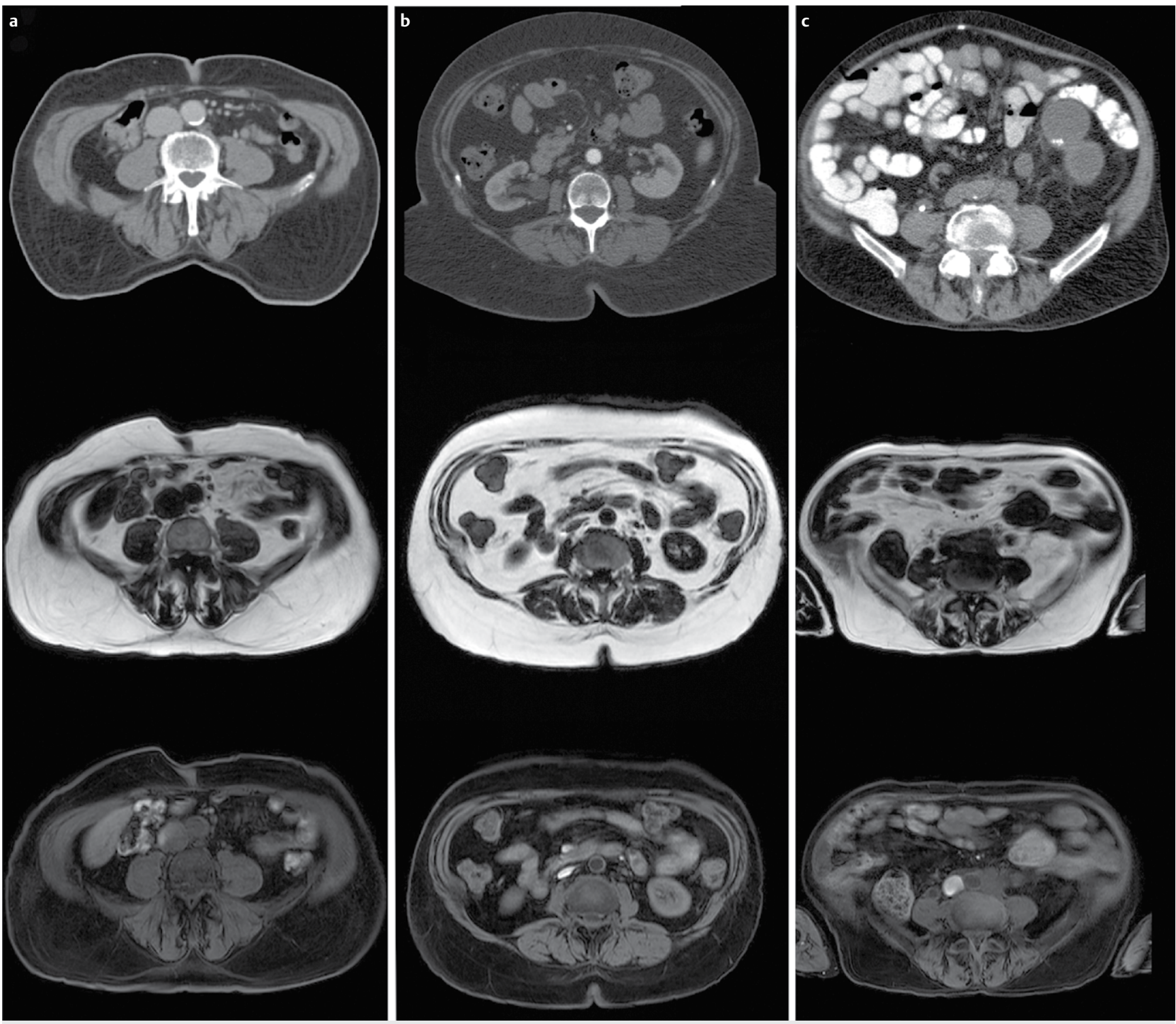

Fig. 3 Both CT (top row) and MRI (middle and bottom rows) are highly reliable modalities to map the spatial distribution of abdominal adipose tissue. The left column a shows a subject with relatively little intra-abdominal adipose tissue and relatively abundant subcutaneous adipose tissue. In the middle column a subject with abundant intra-abdominal as well as subcutaneous adipose tissue is shown, whereas the subject in column c has little subcutaneous adipose tissue, but abundant intra-abdominal adipose tissue. MRI images were obtained using the Dixon technique (bottom row), which allows for separation of the signals from water and adipose tissue and reconstruction of separate images showing both components separately, greatly aiding quantification.

inflammatory cytokines such as TNF- $\alpha$ and by lipopolysaccharide [16]. At a certain point the brain may become desensitized for the inhibitory effects on the food intake, a state called leptin resistance, creating a vicious circle of overeating, gaining weight, and developing insulin resistance $[128,129]$.

Retinol-binding protein-4 (RBP-4) is an adipokine involved in the transport of retinol (vitamin A) throughout the body [130]. It is secreted by hepatocytes, adipocytes, and macrophages $[131,132]$ and is important in regulating glucose homeostasis. Expression of RBP-4 is inversely related to the cellular expression of glucose transporter type 4 [133]. High plasma concentrations of RBP-4 are related to decreased insulin sensitivity and to features of the metabolic syndrome [134,135].

Produced by monocytes, macrophages, and adipocytes, TNF- $\alpha$ is a pro-inflammatory cytokine that plays an important role in the development of insulin resistance by inducing apoptosis of adipocytes [91] and by interfering with the intracellular insulin signaling pathway downstream from the insulin receptor [133].

\section{Anti-inflammatory adipokines}

Adiponectin was discovered in 1996 [136] and is the most intensely studied adipokine. Adiponectin has anti-inflammatory and anti-atherogenic properties, and is positively correlated with insulin sensitivity [137]. Infusion of adiponectin in rats increases insulin sensitivity [138]. There is a strong relation between adiponectin plasma levels and the amount of VAT [139], whether this is an independent effect regardless the size of other adipose tissue depots is subject of debate [74,139-141]. Recently, secreted frizzled related protein 5 (Sfrp5) is identified as a novel adipokine with anti-inflammatory characteristics, being an antagonist of the inflammatory protein WNT5a, preventing WNT5a from binding to its receptor. In Sfrp5 deficient mice, a high calorie diet induced severe glucose intolerance and an accumulation of macrophages in their adipose tissue, both diminished after administration of Sfrp5 [142]. Sfrp5 is downregulated in obese individuals, causing high levels of WNT5a, possibly leading to inflammation and insulin resistance [133]. 
No studies have been performed yet towards the association between Sfrp5 and cardiovascular diseases or DM2.

\section{Adipokine concentrations related to morphology of adipose tissue}

In nonobese individuals, adipose tissue mainly consists of adipocytes, small amounts of pre-adipocytes, lymphocytes, macrophages, fibroblasts, and vascular cells [143]. Two phenotypes of macrophages are abundant in adipose tissue; the M1 macrophages produce pro-inflammatory cytokines $[16,144]$ (IL-6, TNF- $\alpha$ ) and stimulate adipocytes to secrete pro-inflammatory adipokines (leptin, resistin, RBP-4) [133]. M2 macrophages downregulate the synthesis of pro-inflammatory adipokines by adipocytes and upregulate secretion of anti-inflammatory adipokines (SFRP-5, adiponectin) $[16,133]$. In obese individuals, enlarged adipocytes produce chemotactic cytokines that mainly attract M1 macrophages causing an imbalance in pro- and antiinflammatory adipokines, a condition referred to as ATD $[17,145]$.

Plasma levels of adipokines relate to morphologic characteristics of both SAT and VAT [146-148]. Plasma progranulin [148], adiponectin [147], HGF [147], IP-10 [147], and MCP-1 [146] are strongly correlated with the number of infiltrated macrophages and adipocyte size in adipose tissue biopsies. These observa- tions show that plasma levels of adipokines adequately reflect the inflammatory (and dysfunctional) state of the adipose tissue and can therefore be used in diagnosing ATD. $\odot$ Table 1 shows an overview of frequently studied adipokines and their characteristics.

\section{Adipokine concentrations related to metabolic syndrome, DM2, and cardiovascular diseases}

Elevated concentrations of plasma adipokines are associated with the development of the metabolic syndrome. High levels of (pro-inflammatory) leptin, RBP-4, PAI-1, and visfatin and a low level of the protective adiponectin are seen in patients with insulin resistance, metabolic syndrome, and DM2 [45, 94, 98, 111, 134,149-162]. Interestingly, for these adipokines, associations with metabolic syndrome hold even after adjusting for BMI $[45,111,154,158,159,162]$.

For atherosclerotic disease, the association of serum adipokine levels and the development of disease is less distinct. Although a $44 \%$ risk reduction for myocardial infarction was observed in patients with the highest levels of adiponectin [114], later studies and meta-analyses [163-167] showed no relation between levels of adiponectin, leptin, adipsin, resistin, and PAI-1 and the development of atherosclerotic disease (after adjustment for risk factors). The association between ATD and atherosclerotic

Table 1 Overview of frequently studied adipokines and their characteristics.

\begin{tabular}{|c|c|c|c|c|c|}
\hline \multirow[t]{2}{*}{ Adipocytokine } & \multicolumn{5}{|c|}{ Characteristics } \\
\hline & Anti-inflammatory & $\begin{array}{l}\text { Pro-inflam- } \\
\text { matory }\end{array}$ & $\begin{array}{l}\text { Metabolic } \\
\text { function }\end{array}$ & Chemotaxis & Other \\
\hline Adiponectin & + & - & $\uparrow$ & - & \\
\hline Adipsin & + & - & $\uparrow$ & - & \\
\hline Apelin & - & - & $\downarrow$ & - & \\
\hline Adipolin & + & - & $\uparrow$ & - & \\
\hline Chemerin & - & & & & \\
\hline C-reactive protein & - & + & - & - & \\
\hline Ghrelin & - & - & $\downarrow$ & - & \\
\hline Granulocyte colony stimulating factor & - & - & - & + & \\
\hline Hepatic Growth Factor (HGF) & - & - & - & - & Angiogenesis \\
\hline Interleukin 1 beta (IL1- $\beta$ ) & - & + & - & - & \\
\hline Interleukin 6 (IL-6) & $+($ via inhibition IL1) & + & - & - & \\
\hline Interleukin 8 (IL-8) & - & + & - & - & \\
\hline Interleukin 17beta (IL-17ß) & - & + & - & - & \\
\hline Interleukin 21 (IL-21) & - & + & - & - & \\
\hline Interferon gamma induced protein 10 (IP10) & - & + & - & + & \\
\hline Leptin & + & + & $\downarrow \uparrow$ & & \\
\hline \multicolumn{6}{|l|}{ Lipocalin } \\
\hline Monocyte chemoattractant protein 1 (MCP1) & + & - & - & + & \\
\hline Macrophage migration inhibitory factor (MIF) & - & + & - & + & \\
\hline Nerve growth factor (NGF & - & - & - & - & Angiogenesis \\
\hline Omentin & + & - & $\uparrow$ & - & \\
\hline Plasminogen activator inhibitor 1 (PAI-1) & - & - & - & - & Prothrombotic agent \\
\hline Retinol binding protein 4 (RBP-4) & - & + & $\downarrow$ & - & \\
\hline Resistin & - & + & $\downarrow$ & - & \\
\hline Serpin & - & + & - & - & Prothrombotic agent \\
\hline Serum amyloid $A$ protein 1 (SAA1) & - & + & - & - & \\
\hline Secreted frizzled related Protein (SFrP5) & + & - & - & - & \\
\hline Tumor necrosis factor alpha (TNF- $\alpha)$ & - & + & - & $?$ & \\
\hline Thrombopoietin (TPO) & - & - & - & - & Prothrombotic agent \\
\hline Transformation growth factor beta (TGF- $\beta$ ) & + & - & - & - & Pro-apoptotic \\
\hline Visfatin & - & - & $\uparrow$ & - & \\
\hline Vaspin & - & - & $\uparrow$ & - & \\
\hline Vascular cell adhesion molecule 1 & - & + & - & $?$ & \\
\hline
\end{tabular}




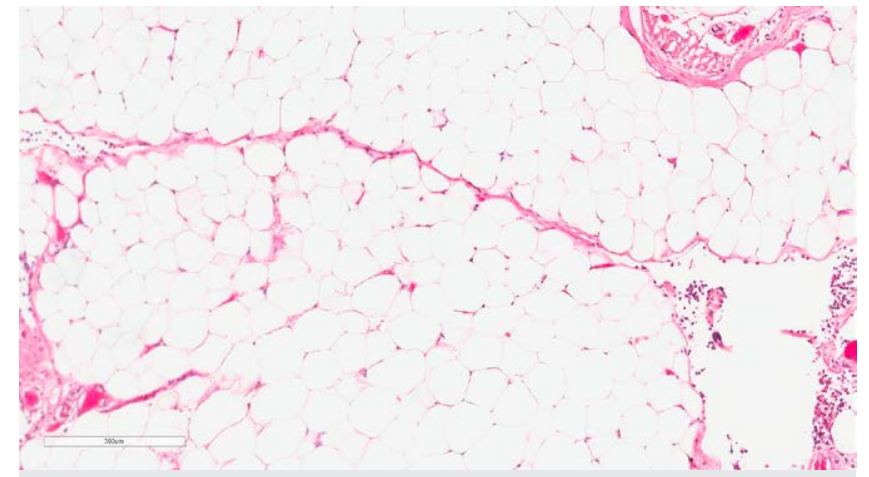

Fig. 4 Visceral adipose tissue biopsy. (Color figure available online only)

disease might be mediated via risk factors of the metabolic syndrome, by development of insulin resistance and inflammation or by direct effects of adipokines on the vessel wall [168].

\section{Reliability of adipokine measurement in plasma}

Plasma adipokine levels are fairly stable over time within individuals and a random peripheral blood sample therefore is a reliable representation of the mean level [169]. Adipokines can be measured by enzyme linked immunosorbent assay (ELISA) [170], and with a multiplex immuno-assay [171]. A fairly good correlation is seen between measurements with multiplex assay and ELISA, next to little cross-reactivity between the antibodies of the different adipokines [171]. This makes multiplex immunoassay a suitable technique for adipokine profiling in patients or cohorts as, in contrast to ELISA, multiple adipokines can be measured in a single measurement.

\section{Clinical recommendation}

Measurement of adipokines is not routinely available in most laboratories and there are no reference values yet for adipokine plasma concentrations, making interpretation of adipokine levels on an individual level difficult and therefore these measurements are not yet useful in daily clinical practice.

\section{Visceral Adiposity Index \\ $\nabla$}

The visceral adiposity index (VAI) was developed to estimate visceral adiposity dysfunction. It is a sex-specific index based on WC, BMI, triglycerides, and HDL-cholesterol [172]. This index is correlated to all factors of the metabolic syndrome and also to the occurrence of cardiovascular events. The association with the metabolic syndrome is not so surprising since 3 factors of the metabolic syndrome are also used in the VAI. The association with cardiovascular events, however, is interesting, since other surrogates for ATD do not show this association. Moreover, VAI is associated with many adipokines, and showed better correlations than WC or BMI. Specific measurements of VAT or SAT were not shown in this study [173]. However, if triglycerides are $>3.15 \mathrm{mmol} / \mathrm{l}$ or if WC is large, the VAI is unreliable [174]. Moreover, the VAI is developed and validated in a Caucasian cohort and it is uncertain how VAI would perform in other populations.

\section{Clinical recommendation}

The VAI could be a reliable method for determining ATD, taking limitations into account.

\section{Adipose Tissue Biopsies to Measure ATD}

Adipose tissue biopsies are potentially the most direct way to evaluate ATD although this is a morphological evaluation and not a functional evaluation. The clinical usefulness of adipose tissue biopsies might be limited, especially with regard to VAT biopsies, as they can only be obtained during abdominal surgery. A needle biopsy of SAT, however, could be performed more easily and could be used in clinical practice. Great advantage of taking biopsies from SAT or VAT is that cellular structures of adipocytes, macrophage infiltration, and ex vivo production of adipokines can be investigated. A key feature of ATD is infiltration of macrophages in adipose tissue [17] and polarization of these macrophages predominantly to the M1-phenotype [175]. Elevated ex vivo production of pro-inflammatory adipokines by adipose tissue biopsies and diminished production of antiinflammatory adipokines [18-20] reflect a state of ATD. In adipose tissue biopsies from subjects with either insulin resistance, metabolic syndrome, or DM2, all features of ATD are seen $[113,141,176-180]$. There is enhanced macrophage infiltration $[113,179]$, higher expression of pro-inflammatory adipokines $[141,178]$, and lower expression of adiponectin $[73,176,177,180]$ as compared to biopsies of overweight, yet metabolically healthy controls. In pericoronary adipose tissue biopsies obtained during cardiac surgery, macrophage infiltration and polarization towards the pro-inflammatory M1-type are more pronounced in patients with coronary atherosclerosis than in those without $[181,182]$ ( $\odot$ Fig. 4). Also, there is a negative association between adiponectin concentrations and macrophage infiltration in adipose tissue in patients undergoing abdominal aortic surgery [147].

After weight loss, either due to a (very) low calorie diet or bariatric surgery, significant improvements in metabolic parameters, such as insulin sensitivity, are seen [183-185]. These effects are measurable directly after the intervention and linger when the weight loss is sustained. Improvements in characteristics of ATD in adipose tissue biopsies develop simultaneously with the metabolic improvements. Reduction of both macrophage infiltration, adipocyte size and inflammatory adipokine concentrations are seen after weight loss due to bariatric surgery and very low calorie diets [186-188]. These effects were seen both shortly (5 days) and 1-3 months after the weight loss intervention, when participants had approximately lost $15 \%$ of their body weight [186-188]. Although VAT is generally believed to be more pathogenic, morphologic changes were seen in both subcutaneous and visceral biopsies [186-188]. However, no direct comparison between morphologic changes in different depots has been studied.

\section{Clinical recommendation}

In daily clinical practice, adipose tissue biopsies merely for diagnostic purposes will not be performed, and therefore studying adipose tissue biopsies will remain primarily a research area.

\section{Conclusion}

$\nabla$

Adipose tissue dysfunction is an imbalance in the production of pro- and anti-inflammatory adipokines leading to insulin resistance, endothelial dysfunction, and eventually to DM2 and vascular diseases. Thus, diagnosing ATD is of clinical relevance and may even be considered a future treatment target. ATD can be diagnosed in both lean and obese individuals. Adipose tissue 
biopsy is considered to be the reference standard for the diagnosis of ATD, as most features of ATD can be directly assessed. Other means are measurement of adipokine plasma levels in peripheral blood samples, although this is not implementable at an individual level due to large intra-individual variations and lack of standardization of the measurements.

Currently, we consider waist circumference, insulin resistance, and the presence of the metabolic syndrome to be the main options to be used in daily clinical practice for estimating ATD. Clearly, it would be a great advantage when more direct diagnostic tools could be used. Of the diagnostic options mentioned, measuring plasma adipokines in blood is, to our opinion, most promising, since this is relatively noninvasive and cheap compared to other options such as imaging and biopsies (especially abdominal adipose tissue biopsies). Possibly, a panel of several pro- and anti-inflammatory adipokines could be compiled, giving clinicians an 'adipokine-score' indicative of the level of ATD.

\section{Conflict of Interest}

\section{$\nabla$}

The authors declare no conflicts of interest.

\section{References}

1 Finucane MM, Stevens GA, Cowan MJ, Danaei G, Lin JK, Paciorek CJ, Singh GM, Gutierrez HR, Lu Y, Bahalim AN, Farzadfar F, Riley LM, Ezzati M. National, regional, and global trends in body-mass index since 1980: systematic analysis of health examination surveys and epidemiological studies with 960 country-years and 9.1 million participants. Lancet 2011; 377: 557-567

2 van Dis, Kromhout D, Geleijnse JM, Boer JM, Verschuren WM. Body mass index and waist circumference predict both 10 -year nonfatal and fatal cardiovascular disease risk: study conducted in 20,000 Dutch men and women aged 20-65 years. Eur J Cardiovasc Prev Rehabil 2009; 16: 729-734

3 Willett WC, Dietz WH, Colditz GA. Guidelines for healthy weight. N Engl J Med 1999; 341: 427-434

4 Reeves GK, Pirie K, Beral V, Green J, Spencer E, Bull D. Cancer incidence and mortality in relation to body mass index in the Million Women Study: cohort study. BMJ 2007; 335: 1134

5 Renehan AG, Tyson M, Egger M, Heller RF, Zwahlen M. Body-mass index and incidence of cancer: a systematic review and meta-analysis of prospective observational studies. Lancet 2008; 371: 569-578

6 Flegal KM, Kit BK, Orpana H, Graubard BI. Association of all-cause mortality with overweight and obesity using standard body mass index categories: a systematic review and meta-analysis. JAMA 2013; 309: 71-82

7 Faber DR, de Groot PG, Visseren FL. Role of adipose tissue in haemostasis, coagulation and fibrinolysis. Obes Rev 2009; 10: 554-563

8 Kip KE, Marroquin OC, Kelley DE, Johnson BD, Kelsey SF, Shaw LJ, Rogers WJ, Reis SE. Clinical importance of obesity versus the metabolic syndrome in cardiovascular risk in women: a report from the Women's Ischemia Syndrome Evaluation (WISE) study. Circulation 2004; 109: 706-713

9 Voulgari C, Tentolouris N, Dilaveris P, Tousoulis D, Katsilambros $N$, Stefanadis $C$. Increased heart failure risk in normal-weight people with metabolic syndrome compared with metabolically healthy obese individuals. J Am Coll Cardiol 2011; 58: 1343-1350

10 Primeau V, Coderre L, Karelis AD, Brochu M, Lavoie ME, Messier V, Sladek R, Rabasa-Lhoret $R$. Characterizing the profile of obese patients who are metabolically healthy. Int J Obes (Lond) 2011; 35: 971-981

11 Meigs JB, Wilson PW, Fox CS, Vasan RS, Nathan DM, Sullivan LM, D'Agostino RB. Body mass index, metabolic syndrome, and risk of type 2 diabetes or cardiovascular disease. J Clin Endocrinol Metab 2006; 91: 2906-2912

12 Succurro E, Marini MA, Frontoni S, Hribal ML, Andreozzi F, Lauro R, Perticone F, Sesti $G$. Insulin secretion in metabolically obese, but normal weight, and in metabolically healthy but obese individuals. Obesity (Silver Spring) 2008; 16: 1881-1886
13 Wildman RP, Muntner P, Reynolds K, McGinn AP, Rajpathak S, WylieRosett J, Sowers MR. The obese without cardiometabolic risk factor clustering and the normal weight with cardiometabolic risk factor clustering: prevalence and correlates of 2 phenotypes among the US population (NHANES 1999-2004). Arch Intern Med 2008; 168: 16171624

14 Karelis $A D$, Brochu $M$, Rabasa-Lhoret $R$. Can we identify metabolically healthy but obese individuals (MHO)? Diabetes Metab 2004; 30: 569-572

15 Westerink J, Visseren FL. Pharmacological and non-pharmacological interventions to influence adipose tissue function. Cardiovasc Diabetol 2011; 10: 13

16 Gordon S, Taylor PR. Monocyte and macrophage heterogeneity. Nat Rev Immunol 2005; 5: 953-964

17 Weisberg SP, McCann D, Desai M, Rosenbaum M, Leibel RL, Ferrante $A W \mathrm{Jr}$. Obesity is associated with macrophage accumulation in adipose tissue. J Clin Invest 2003; 112: 1796-1808

18 Hajer GR, van Haeften TW, Visseren FL. Adipose tissue dysfunction in obesity, diabetes, and vascular diseases. Eur Heart J 2008; 29: 29592971

19 Permana PA, Zhang W, Wabitsch M, Fischer-Posovszky P, Duckworth $W C$, Reaven PD. Pioglitazone reduces inflammatory responses of human adipocytes to factors secreted by monocytes/macrophages. Am J Physiol Endocrinol Metab 2009; 296: E1076-E1084

20 Ruan H, Hacohen N, Golub TR, Van PL, Lodish HF. Tumor necrosis factor-alpha suppresses adipocyte-specific genes and activates expression of preadipocyte genes in 3T3-L1 adipocytes: nuclear factor-kappaB activation by TNF-alpha is obligatory. Diabetes 2002; 51: 1319-1336

21 Alberti KG, Zimmet P, Shaw J. The metabolic syndrome - a new worldwide definition. Lancet 2005; 366: 1059-1062

22 Grundy SM, Cleeman JI, Daniels SR, Donato KA, Eckel RH, Franklin BA, Gordon DJ, Krauss RM, Savage PJ, Smith SC Jr., Spertus JA, Costa F. Diagnosis and management of the metabolic syndrome: an American Heart Association/National Heart, Lung, and Blood Institute Scientific Statement. Circulation 2005; 112: 2735-2752

23 Durward CM, Hartman TJ, Nickols-Richardson SM. All-cause mortality risk of metabolically healthy obese individuals in NHANES III. J Obes 2012460321

24 Jeon CY, Lokken RP, Hu FB, van Dam RM. Physical activity of moderate intensity and risk of type 2 diabetes: a systematic review. Diabetes Care 2007; 30: 744-752

25 Rana JS, Li TY, Manson JE, Hu FB. Adiposity compared with physical inactivity and risk of type 2 diabetes in women. Diabetes Care 2007; 30: $53-58$

26 Cnop M. Fatty acids and glucolipotoxicity in the pathogenesis of Type 2 diabetes. Biochem Soc Trans 2008; 36: 348-352

27 Galgani JE, Uauy RD, Aguirre CA, Diaz EO. Effect of the dietary fat quality on insulin sensitivity. Br J Nutr 2008; 100: 471-479

28 Curhan GC, Chertow GM, Willett WC, Spiegelman D, Colditz GA, Manson JE, Speizer FE, Stampfer MJ. Birth weight and adult hypertension and obesity in women. Circulation 1996; 94: 1310-1315

29 Freathy RM, Bennett AJ, Ring SM, Shields B, Groves CJ, Timpson NJ, Weedon MN, Zeggini E, Lindgren CM, Lango H, Perry JR, Pouta A, Ruokonen A, Hypponen E, Power C, Elliott P, Strachan DP, Jarvelin MR, Smith GD, McCarthy MI, Frayling TM, Hattersley AT. Type 2 diabetes risk alleles are associated with reduced size at birth. Diabetes 2009; 58: $1428-1433$

30 Bottcher Y, Korner A, Reinehr T, Enigk B, Kiess W, Stumvoll M, Kovacs P. ENPP1 variants and haplotypes predispose to early onset obesity and impaired glucose and insulin metabolism in German obese children. J Clin Endocrinol Metab 2006; 91: 4948-4952

31 Stancakova A, Kuulasmaa T, Paananen J, Jackson AU, Bonnycastle $L L$ Collins FS, Boehnke M, Kuusisto J, Laakso M. Association of 18 confirmed susceptibility loci for type 2 diabetes with indices of insulin release, proinsulin conversion, and insulin sensitivity in 5,327 nondiabetic Finnish men. Diabetes 2009; 58: 2129-2136

32 Emdin M, Gastaldelli A, Muscelli E, Macerata A, Natali A, Camastra S, Ferrannini E. Hyperinsulinemia and autonomic nervous system dysfunction in obesity: effects of weight loss. Circulation 2001; 103 : 513-519

33 Mohamed-Ali V, Flower L, Sethi J, Hotamisligil G, Gray R, Humphries $S E$, York DA, Pinkney J. beta-Adrenergic regulation of IL-6 release from adipose tissue: in vivo and in vitro studies. J Clin Endocrinol Metab 2001; 86: 5864-5869 
34 Haffner SM, Miettinen H, Gaskill SP, Stern MP. Decreased insulin secretion and increased insulin resistance are independently related to the 7-year risk of NIDDM in Mexican-Americans. Diabetes 1995; 44: 1386-1391

35 Evans JL, Goldfine ID, Maddux BA, Grodsky GM. Are oxidative stressactivated signaling pathways mediators of insulin resistance and beta-cell dysfunction? Diabetes 2003; 52: 1-8

36 Cheng KH, Chu CS, Lee KT, Lin TH, Hsieh CC, Chiu CC, Voon WC, Sheu $S H$, Lai WT. Adipocytokines and proinflammatory mediators from abdominal and epicardial adipose tissue in patients with coronary artery disease. Int J Obes (Lond) 2008; 32: 268-274

37 Davy KP, Orr JS. Sympathetic nervous system behavior in human obesity. Neurosci Biobehav Rev 2009; 33: 116-124

38 Spiroglou SG, Kostopoulos CG, Varakis JN, Papadaki HH. Adipokines in periaortic and epicardial adipose tissue: differential expression and relation to atherosclerosis. J Atheroscler Thromb 2010; 17: 115-130

39 Janssen I, Katzmarzyk PT, Ross R. Waist circumference and not body mass index explains obesity-related health risk. Am J Clin Nutr 2004; 79: $379-384$

40 Schneider HJ, Glaesmer H, Klotsche J, Bohler S, Lehnert H, Zeiher AM, Marz W, Pittrow D, Stalla GK, Wittchen HU. Accuracy of anthropometric indicators of obesity to predict cardiovascular risk. J Clin Endocrinol Metab 2007; 92: 589-594

41 Schneider HJ, Friedrich N, Klotsche J, Pieper L, Nauck M, John U, Dorr $M$, Felix $S$, Lehnert $H$, Pittrow D, Silber S, Volzke H, Stalla GK, Wallaschofski $H$, Wittchen $H U$. The predictive value of different measures of obesity for incident cardiovascular events and mortality. J Clin Endocrinol Metab 2010; 95: 1777-1785

42 Ackermann D, Jones J, Barona J, Calle MC, Kim JE, LaPia B, Volek JS, McIntosh M, Kalynych C, Najm W, Lerman RH, Fernandez ML. Waist circumference is positively correlated with markers of inflammation and negatively with adiponectin in women with metabolic syndrome. Nutr Res 2011; 31: 197-204

43 Bahia L, Aguiar LG, Villela N, Bottino D, Godoy-Matos AF, Geloneze B, Tambascia $M$, Bouskela E. Relationship between adipokines, inflammation, and vascular reactivity in lean controls and obese subjects with metabolic syndrome. Clinics (Sao Paulo) 2006; 61: 433-440

44 Conroy SM, Chai W, Lim U, Franke AA, Cooney RV, Maskarinec G. Leptin, adiponectin, and obesity among Caucasian and Asian women. Mediators Inflamm 2011253580

45 Stenholm S, Koster A, Alley DE, Visser M, Maggio M, Harris TB, Egan $J M$, Bandinelli S, Guralnik JM, Ferrucci L. Adipocytokines and the metabolic syndrome among older persons with and without obesity: the InCHIANTI study. Clin Endocrinol (Oxf) 2010; 73: 55-65

46 Lacerte $G$, Langlois MF, Doyon M, Brown C, Carpentier AC, Hivert MF. Differential impact of changes in adiposity distribution on insulin resistance and adiponectin variations over 4 years in normal weight young adults. Horm Metab Res 2014; 46: 354-359

47 Alvehus M, Simonyte K, Andersson T, Soderstrom I, Buren J, Rask E, Mattsson C, Olsson T. Adipose tissue IL-8 is increased in normal weight women after menopause and reduced after gastric bypass surgery in obese women. Clin Endocrinol (Oxf) 2012; 77: 684-690

48 Michaud A, Drolet R, Noel S, Paris G, Tchernof A. Visceral fat accumulation is an indicator of adipose tissue macrophage infiltration in women. Metabolism 2012; 61: 689-698

49 Arnlov J, Ingelsson E, Sundstrom J, Lind L. Impact of body mass index and the metabolic syndrome on the risk of cardiovascular disease and death in middle-aged men. Circulation 2010; 121: 230-236

50 Song Y, Manson JE, Meigs JB, Ridker PM, Buring JE, Liu S. Comparison of usefulness of body mass index versus metabolic risk factors in predicting 10-year risk of cardiovascular events in women. Am J Cardiol 2007; 100: 1654-1658

51 Farin HM, Abbasi F, Reaven GM. Comparison of body mass index versus waist circumference with the metabolic changes that increase the risk of cardiovascular disease in insulin-resistant individuals. Am J Cardiol 2006; 98: 1053-1056

52 Ferrannini E, Natali A, Bell P, Cavallo-Perin P, Lalic N, Mingrone G. Insulin resistance and hypersecretion in obesity. European Group for the Study of Insulin Resistance (EGIR). J Clin Invest 1997; 100: 11661173

53 Bonora E, Micciolo R, Ghiatas AA, Lancaster JL, Alyassin A, Muggeo M, DeFronzo $R A$. Is it possible to derive a reliable estimate of human visceral and subcutaneous abdominal adipose tissue from simple anthropometric measurements? Metabolism 1995; 44: 1617-1625

54 Chan DC, Watts GF, Barrett PH, Burke V. Waist circumference, waistto-hip ratio and body mass index as predictors of adipose tissue compartments in men. QJM 2003; 96: 441-447
55 Janssen I, Heymsfield SB, Allison DB, Kotler DP, Ross R. Body mass index and waist circumference independently contribute to the prediction of nonabdominal, abdominal subcutaneous, and visceral fat. Am J Clin Nutr 2002; 75: 683-688

56 Fox CS, Massaro JM, Hoffmann U, Pou KM, Maurovich-Horvat P, Liu CY, Vasan RS, Murabito JM, Meigs JB, Cupples LA, D'Agostino RB Sr., O'Donnell CJ. Abdominal visceral and subcutaneous adipose tissue compartments: association with metabolic risk factors in the Framingham Heart Study. Circulation 2007; 116: 39-48

57 De Lucia RE, Sleigh A, Finucane FM, Brage S, Stolk RP, Cooper C, Sharp SJ, Wareham NJ, Ong KK. Ultrasound measurements of visceral and subcutaneous abdominal thickness to predict abdominal adiposity among older men and women. Obesity (Silver Spring) 2010; 18: 625-631

58 Eastwood SV, Tillin T, Wright A, Heasman J, Willis J, Godsland IF, Forouhi $N$, Whincup $P$, Hughes $A D$, Chaturvedi N. Estimation of CTderived abdominal visceral and subcutaneous adipose tissue depots from anthropometry in Europeans, South Asians and African Caribbeans. PLoS One 2013; 8: e75085

59 Klopfenstein BJ, Kim MS, Krisky CM, Szumowski J, Rooney WD, Purnell JQ. Comparison of 3T MRI and CT for the measurement of visceral and subcutaneous adipose tissue in humans. $\mathrm{Br} \mathrm{J}$ Radiol 2012; 85: e826-e830

60 Schrover IM, Leiner T, Klomp DW, Wijnen JP, Uiterwaal CS, Spiering W, Visseren FL. Feasibility and reproducibility of free fatty acid profiling in abdominal adipose tissue with $\mathrm{H}$-magnetic resonance spectroscopy at 3T. Differences between lean and obese individuals J Magn Reson Imaging 2014; 40: 423-481

61 Kuchenbecker WK, Groen H, Pel H, Bolster JH, Wolffenbuttel BH, Land $J A$, Hoek A, Corpeleijn E. Validation of the measurement of intraabdominal fat between ultrasound and CT scan in women with obesity and infertility. Obesity (Silver Spring) 2014; 22: 537-544

62 Stolk RP, Wink O, Zelissen PM, Meijer R, van Gils AP, Grobbee DE. Validity and reproducibility of ultrasonography for the measurement of intra-abdominal adipose tissue. Int J Obes Relat Metab Disord 2001; 25: 1346-1351

63 Armellini F, Zamboni M, Robbi R, Todesco T, Rigo L, Bergamo-Andreis $I A$, Bosello 0 . Total and intra-abdominal fat measurements by ultrasound and computerized tomography. Int J Obes Relat Metab Disord 1993; 17: 209-214

64 Arif H, Racette SB, Villareal DT, Holloszy JO, Weiss EP. Comparison of methods for assessing abdominal adipose tissue from magnetic resonance images. Obesity (Silver Spring) 2007; 15: 2240-2244

65 Thormer G, Bertram HH, Garnov N, Peter V, Schutz T, Shang E, Bluher $M$, Kahn T, Busse H. Software for automated MRI-based quantification of abdominal fat and preliminary evaluation in morbidly obese patients. J Magn Reson Imaging 2013; 37: 1144-1150

66 Eggers H, Bornert P. Chemical shift encoding-based water-fat separation methods. J Magn Reson Imaging 2014; 40: 251-268

$67 \mathrm{Ma}$ J. Dixon techniques for water and fat imaging. J Magn Reson Imaging 2008; 28: 543-558

68 Tadokoro N, Shinomiya M, Yoshinaga M, Takahashi H, Matsuoka K Miyashita Y, Nakamura M, Kuribayashi N. Visceral fat accumulation in Japanese high school students and related atherosclerotic risk factors. J Atheroscler Thromb 2010; 17: 546-557

69 Indulekha K, Anjana RM, Surendar J, Mohan V. Association of visceral and subcutaneous fat with glucose intolerance, insulin resistance, adipocytokines and inflammatory markers in Asian Indians (CURES113). Clin Biochem 2011; 44: 281-287

70 Jia W, Wu H, Bao Y, Wang C, Lu J, Zhu J, Xiang K. Association of serum retinol-binding protein 4 and visceral adiposity in Chinese subjects with and without type 2 diabetes. J Clin Endocrinol Metab 2007; 92: 3224-3229

71 Lee JW, Im JA, Lee HR, Shim JY, Youn BS, Lee DC. Visceral adiposity is associated with serum retinol binding protein-4 levels in healthy women. Obesity (Silver Spring) 2007; 15: 2225-2232

72 Saito T, Murata M, Otani T, Tamemoto H, Kawakami M, Ishikawa SE. Association of subcutaneous and visceral fat mass with serum concentrations of adipokines in subjects with type 2 diabetes mellitus. Endocr J 2012; 59: 39-45

73 Drolet R, Belanger C, Fortier M, Huot C, Mailloux J, Legare D, Tchernof A. Fat depot-specific impact of visceral obesity on adipocyte adiponectin release in women. Obesity (Silver Spring) 2009; 17: 424-430

74 Fujikawa $R$, Ito $C$, Nakashima $R$, Orita $Y$, Ohashi $N$. Is there any association between subcutaneous adipose tissue area and plasma total and high molecular weight adiponectin levels? Metabolism 2008; 57: 506-510 
75 Neeland IJ, Ayers CR, Rohatgi AK, Turer AT, Berry JD, Das SR, Vega GL, Khera A, McGuire DK, Grundy SM, de Lemos JA. Associations of visceral and abdominal subcutaneous adipose tissue with markers of cardiac and metabolic risk in obese adults. Obesity (Silver Spring) 2013; 21: E439-E447

76 Dorresteijn JA, Spiering W, Van Der GY, Visseren FL. Relation between adiposity and hypertension persists after onset of clinically manifest arterial disease. J Hypertens 2012; 30: 2331-2337

77 Fox CS, Hwang SJ, Massaro JM, Lieb K, Vasan RS, O'Donnell CJ, Hoffmann U. Relation of subcutaneous and visceral adipose tissue to coronary and abdominal aortic calcium (from the Framingham Heart Study). Am J Cardiol 2009; 104: 543-547

78 Sironi AM, Petz R, De MD, Buzzigoli E, Ciociaro D, Positano V, Lombardi $M$, Ferrannini E, Gastaldelli A. Impact of increased visceral and cardiac fat on cardiometabolic risk and disease. Diabet Med 2012; 29: 622627

79 Pou KM, Massaro JM, Hoffmann U, Lieb K, Vasan RS, O'Donnell CJ, Fox CS. Patterns of abdominal fat distribution: the Framingham Heart Study. Diabetes Care 2009; 32: 481-485

80 Lee K, Lee S, Kim YJ, Kim YJ. Waist circumference, dual-energy X-ray absortiometrically measured abdominal adiposity, and computed tomographically derived intra-abdominal fat area on detecting metabolic risk factors in obese women. Nutrition 2008; 24: 625-631

81 Graaf Rd. In vivo NMR Spectroscopy. 2nd ed.Chichester: Wiley; 2007

82 Lundbom J, Hakkarainen A, Fielding B, Soderlund S, Westerbacka J, Taskinen MR, Lundbom N. Characterizing human adipose tissue lipids by long echo time $1 \mathrm{H}-\mathrm{MRS}$ in vivo at 1.5 Tesla: validation by gas chromatography. NMR Biomed 2010; 23: 466-472

83 Dimitrov IE, Douglas D, Ren J, Smith NB, Webb AG, Sherry AD, Malloy CR. In vivo determination of human breast fat composition by (1)H magnetic resonance spectroscopy at 7T. Magn Reson Med 2012; 67: 20-26

84 Ren J, Dimitrov I, Sherry AD, Malloy CR. Composition of adipose tissue and marrow fat in humans by $1 \mathrm{H}$ NMR at 7 Tesla. J Lipid Res 2008; 49: 2055-2062

85 van der Meer RW, Hammer S, Lamb HJ, Frolich M, Diamant M, Rijzewijk LJ, de RA, Romijn JA, Smit JW. Effects of short-term high-fat, highenergy diet on hepatic and myocardial triglyceride content in healthy men. J Clin Endocrinol Metab 2008; 93: 2702-2708

86 van Werven Jr., Hoogduin JM, Nederveen AJ, van Vliet AA, Wajs E, Vandenberk P, Stroes ES, Stoker J. Reproducibility of 3.0 Tesla magnetic resonance spectroscopy for measuring hepatic fat content. J Magn Reson Imaging 2009; 30: 444-448

87 Magkos F. Putative factors that may modulate the effect of exercise on liver fat: insights from animal studies. J Nutr Metab. 2012827417

88 Finucane FM, Sharp SJ, Purslow LR, Horton K, Horton J, Savage DB, Brage S, Besson H, De Lucia RE, Sleigh A, Martin HJ, Aihie SA, Cooper C, Ekelund U, Griffin SJ, Wareham NJ. The effects of aerobic exercise on metabolic risk, insulin sensitivity and intrahepatic lipid in healthy older people from the Hertfordshire Cohort Study: a randomised controlled trial. Diabetologia 2010; 53: 624-631

89 Hammer S, van der Meer RW, Lamb HJ, de Boer HH, Bax JJ, de RA, Romijn JA, Smit JW. Short-term flexibility of myocardial triglycerides and diastolic function in patients with type 2 diabetes mellitus. Am J Physiol Endocrinol Metab 2008; 295: E714-E718

90 Lundbom J, Hakkarainen A, Soderlund S, Westerbacka J, Lundbom N, Taskinen MR. Long-TE 1H MRS suggests that liver fat is more saturated than subcutaneous and visceral fat. NMR Biomed 2011; 24: 238-245

91 Goossens GH. The role of adipose tissue dysfunction in the pathogenesis of obesity-related insulin resistance. Physiol Behav 2008; 94: 206-218

92 Otten J, Ahren B, Olsson T. Surrogate measures of insulin sensitivity vs the hyperinsulinaemic-euglycaemic clamp: a meta-analysis. Are there not some surrogate indexes lost in this story? Reply to Bastard JP, Rabasa-Lhoret R, Laville M, and Disse E [letter]. Diabetologia 2015; 58: 416-417

93 Alikasifoglu A, Gonc N, Ozon ZA, Sen Y, Kandemir N. The relationship between serum adiponectin, tumor necrosis factor-alpha, leptin levels and insulin sensitivity in childhood and adolescent obesity: adiponectin is a marker of metabolic syndrome. J Clin Res Pediatr Endocrinol 2009; 1: 233-239

94 Hung J, McQuillan BM, Thompson PL, Beilby JP. Circulating adiponectin levels associate with inflammatory markers, insulin resistance and metabolic syndrome independent of obesity. Int J Obes (Lond) 2008; 32: 772-779
95 Mazzali G, Di FV, Zoico E, Fantin F, Zamboni G, Benati C, Bambara V, Negri $M$, Bosello $O$, Zamboni $M$. Interrelations between fat distribution, muscle lipid content, adipocytokines, and insulin resistance: effect of moderate weight loss in older women. Am J Clin Nutr 2006; 84: 1193-1199

96 Taniguchi A, Fukushima M, Ohya M, Nakai Y, Yoshii S, Nagasaka S, Matsumoto K, Taki Y, Kuroe A, Nishimura F, Seino Y. Interleukin 6, adiponectin, leptin, and insulin resistance in nonobese Japanese type 2 diabetic patients. Metabolism 2006; 55: 258-262

97 Zoico E, Di FV, Mazzali G, Vettor R, Fantin F, Bissoli L, Guariento S, Bosello $\mathrm{O}$, Zamboni $M$. Adipocytokines, fat distribution, and insulin resistance in elderly men and women. J Gerontol A Biol Sci Med Sci 2004; 59: M935-M939

98 Esteghamati A, Khalilzadeh O, Anvari M, Rashidi A, Mokhtari M, Nakhjavani M. Association of serum leptin levels with homeostasis model assessment-estimated insulin resistance and metabolic syndrome: the key role of central obesity. Metab Syndr Relat Disord 2009; 7: 447-452

99 Silha JV, Krsek M, Skrha J, Sucharda P, Nyomba BL, Murphy LJ. Plasma resistin, leptin and adiponectin levels in non-diabetic and diabetic obese subjects. Diabet Med 2004; 21: 497-499

100 Moller DE. Potential role of TNF-alpha in the pathogenesis of insulin resistance and type 2 diabetes. Trends Endocrinol Metab 2000; 11: 212-217

101 Civera M, Urios A, Garcia-Torres ML, Ortega J, Martinez-Valls J, Cassinello $N$, del Olmo JA, Ferrandez A, Rodrigo JM, Montoliu C. Relationship between insulin resistance, inflammation and liver cell apoptosis in patients with severe obesity. Diabetes Metab Res Rev 2010; 26 : 187-192

102 Daniele G, Guardado MR, Winnier D, Fiorentino TV, Pengou Z, Cornell J, Andreozzi F, Jenkinson C, Cersosimo E, Federici M, Tripathy D, Folli $F$. The inflammatory status score including IL-6, TNF-alpha, osteopontin, fractalkine, MCP-1 and adiponectin underlies wholebody insulin resistance and hyperglycemia in type 2 diabetes mellitus. Acta Diabetol 2014; 51: 123-131

103 Stienstra R, van Diepen JA, Tack CJ, Zaki MH, van d V, Perera D, Neale $G A$, Hooiveld GJ, Hijmans A, Vroegrijk I, van den BS, Romijn J, Rensen $P C$, Joosten LA, Netea MG, Kanneganti TD. Inflammasome is a central player in the induction of obesity and insulin resistance. Proc Natl Acad Sci U S A 2011; 108: 15324-15329

104 Shapiro H, Pecht T, Shaco-Levy R, Harman-Boehm I, Kirshtein B, Kuperman Y, Chen A, Bluher M, Shai I, Rudich A. Adipose tissue foam cells are present in human obesity. J Clin Endocrinol Metab 2013; 98: 1173-1181

105 Tabak AG, Herder C, Rathmann W, Brunner EJ, Kivimaki M. Prediabetes: a high-risk state for diabetes development. Lancet 2012; 379: 2279-2290

106 Cheal KL, Abbasi F, Lamendola C, McLaughlin T, Reaven GM, Ford ES Relationship to insulin resistance of the adult treatment panel III diagnostic criteria for identification of the metabolic syndrome. Diabetes 2004; 53: 1195-1200

107 Jeppesen J, Hansen TW, Rasmussen S, Ibsen H, Torp-Pedersen C, Madsbad $S$. Insulin resistance, the metabolic syndrome, and risk of incident cardiovascular disease: a population-based study. J Am Coll Cardiol 2007; 49: 2112-2119

108 Onat A, Hergenc G, Turkmen S, Yazici M, Sari I, Can G. Discordance between insulin resistance and metabolic syndrome: features and associated cardiovascular risk in adults with normal glucose regulation. Metabolism 2006; 55: 445-452

109 Gast KB, Tjeerdema N, Stijnen T, Smit JW, Dekkers OM. Insulin Resistance and Risk of Incident Cardiovascular Events in Adults without Diabetes: Meta-Analysis. PLoS One 2012; 7: e52036

110 Ausk KJ, Boyko EJ, Ioannou GN. Insulin resistance predicts mortality in nondiabetic individuals in the U.S. Diabetes Care 2010; 33: 11791185

111 Zhuo Q Wang ZQ Fu P, Piao JH, Tian Y, Xu J, Yang XG. Association between adiponectin and metabolic syndrome in older adults from major cities of China. Biomed Environ Sci 2010; 23: 53-61

112 Chen SJ, Yen CH, Huang YC, Lee BJ, Hsia S, Lin PT. Relationships between inflammation, adiponectin, and oxidative stress in metabolic syndrome. PLoS One 2012; 7: e45693

113 Bremer AA, Devaraj S, Afify A, Jialal I. Adipose tissue dysregulation in patients with metabolic syndrome. J Clin Endocrinol Metab 2011; 96: E1782-E1788

114 Pischon T, Girman CJ, Hotamisligil GS, Rifai N, Hu FB, Rimm EB. Plasma adiponectin levels and risk of myocardial infarction in men. JAMA 2004; 291: 1730-1737 
115 Hong $Y$, Jin X, Mo J, Lin HM, Duan Y, Pu M, Wolbrette DL, Liao D. Metabolic syndrome, its preeminent clusters, incident coronary heart disease and all-cause mortality-results of prospective analysis for the Atherosclerosis Risk in Communities study. J Intern Med 2007; 262: 113-122

116 Malik S, Wong ND, Franklin SS, Kamath TV, L'Italien GJ, Pio JR, Williams GR. Impact of the metabolic syndrome on mortality from coronary heart disease, cardiovascular disease, and all causes in United States adults. Circulation 2004; 110: 1245-1250

117 Mukai N, Doi Y, Ninomiya T, Hata J, Yonemoto $K$, Iwase M, Iida $M$, Kiyohara $Y$. Impact of metabolic syndrome compared with impaired fasting glucose on the development of type 2 diabetes in a general Japanese population: the Hisayama study. Diabetes Care 2009; 32: 2288-2293

118 Heinonen MV, Laaksonen DE, Karhu T, Karhunen L, Laitinen T, Kainulainen S, Rissanen A, Niskanen L, Herzig KH. Effect of diet-induced weight loss on plasma apelin and cytokine levels in individuals with the metabolic syndrome. Nutr Metab Cardiovasc Dis 2009; 19: 626633

119 Lee CG, Carr MC, Murdoch SJ, Mitchell E, Woods NF, Wener MH, Chandler WL, Boyko EJ, Brunzell JD. Adipokines, inflammation, and visceral adiposity across the menopausal transition: a prospective study. J Clin Endocrinol Metab 2009; 94: 1104-1110

120 Liang KW, Sheu WH, Lee WL, Liu TJ, Ting CT, Hsieh YC, Wang KY, Chen $Y T$, Lee WJ. Decreased circulating protective adiponectin level is associated with angiographic coronary disease progression in patients with angina pectoris. Int J Cardiol 2008; 129: 76-80

121 Mente A, Razak F, Blankenberg S, Vuksan V, Davis AD, Miller R, Teo K, Gerstein H, Sharma AM, Yusuf S, Anand SS. Ethnic variation in adiponectin and leptin levels and their association with adiposity and insulin resistance. Diabetes Care 2010; 33: 1629-1634

122 Varady KA, Tussing L, Bhutani S, Braunschweig CL. Degree of weight loss required to improve adipokine concentrations and decrease fat cell size in severely obese women. Metabolism 2009; 58: 1096-1101

123 Yaturu S, Daberry RP, Rains J, Jain S. Resistin and adiponectin levels in subjects with coronary artery disease and type 2 diabetes. Cytokine 2006; 34: 219-223

124 Yaturu S, Rains J, Jain SK. Relationship of elevated osteoprotegerin with insulin resistance, CRP, and TNF-alpha levels in men with type 2 diabetes. Cytokine 2008; 44: 168-171

125 Tian $F$, Luo $R$, Zhao $Z, W u Y$, Ban $D$. Blockade of the RAS increases plasma adiponectin in subjects with metabolic syndrome and enhances differentiation and adiponectin expression of human preadipocytes. Exp Clin Endocrinol Diabetes 2010; 118: 258-265

126 Halaas JL, Gajiwala KS, Maffei M, Cohen SL, Chait BT, Rabinowitz D, Lallone RL, Burley SK, Friedman JM. Weight-reducing effects of the plasma protein encoded by the obese gene. Science 1995; 269: 543-546

127 Zhang Y, Proenca R, Maffei M, Barone M, Leopold L, Friedman JM. Positional cloning of the mouse obese gene and its human homologue. Nature 1994; 372: 425-432

128 Considine RV, Premkumar A, Reynolds JC, Sebring NG, Ricks M, Sumner AE. Adiponectin and leptin in African Americans. Obesity (Silver Spring) 2008; 16: 428-434

129 Maury E, Ehala-Aleksejev K, Guiot Y, Detry R, Vandenhooft A, Brichard SM. Adipokines oversecreted by omental adipose tissue in human obesity. Am J Physiol Endocrinol Metab 2007; 293: E656-E665

130 Eriksson U, Das K, Busch C, Nordlinder H, Rask L, Sundelin J, Sallstrom $J$, Peterson PA. Cellular retinol-binding protein. Quantitation and distribution. J Biol Chem 1984; 259: 13464-13470

131 Broch M, Ramirez R, Auguet MT, Alcaide MJ, Aguilar C, Garcia-Espana $A$, Richart C. Macrophages are novel sites of expression and regulation of retinol binding protein-4 (RBP4). Physiol Res 2010; 59: 299-303

132 Yang $Q$, Graham TE, Mody N, Preitner F, Peroni OD, Zabolotny JM, Kotani K, Quadro L, Kahn BB. Serum retinol binding protein 4 contributes to insulin resistance in obesity and type 2 diabetes. Nature 2005; 436: 356-362

133 Ouchi N, Parker JL, Lugus JJ, Walsh K. Adipokines in inflammation and metabolic disease. Nat Rev Immunol 2011; 11: 85-97

134 Graham TE, Yang Q Bluher M, Hammarstedt A, Ciaraldi TP, Henry RR, Wason CJ, Oberbach A, Jansson PA, Smith U, Kahn BB. Retinol-binding protein 4 and insulin resistance in lean, obese, and diabetic subjects. N Engl J Med 2006; 354: 2552-2563

135 Ebert T, Roth I, Richter J, Tonjes A, Kralisch S, Lossner U, Kratzsch J, Bluher M, Stumvoll M, Fasshauer M. Different associations of adipokines in lean and healthy adults. Horm Metab Res 2014; 46: 41-47

$136 \mathrm{Hu}$ E, Liang P, Spiegelman BM. AdipoQ is a novel adipose-specific gene dysregulated in obesity. J Biol Chem 1996; 271: 10697-10703
137 Kadowaki T, Yamauchi T. Adiponectin and adiponectin receptors. Endocr Rev 2005; 26: 439-451

138 Park S, Kim DS, Kwon DY, Yang HJ. Long-term central infusion of adiponectin improves energy and glucose homeostasis by decreasing fat storage and suppressing hepatic gluconeogenesis without changing food intake. J Neuroendocrinol 2011; 23: 687-698

139 Cote M, Mauriege P, Bergeron J, Almeras N, Tremblay A, Lemieux I, Despres JP. Adiponectinemia in visceral obesity: impact on glucose tolerance and plasma lipoprotein and lipid levels in men. J Clin Endocrinol Metab 2005; 90: 1434-1439

140 Frederiksen L, Nielsen TL, Wraae K, Hagen C, Frystyk J, Flyvbjerg A, Brixen $K$, Andersen $M$. Subcutaneous rather than visceral adipose tissue is associated with adiponectin levels and insulin resistance in young men. J Clin Endocrinol Metab 2009; 94: 4010-4015

141 Samaras K, Botelho NK, Chisholm DJ, Lord RV. Subcutaneous and visceral adipose tissue gene expression of serum adipokines that predict type 2 diabetes. Obesity (Silver Spring) 2010; 18: 884-889

142 Ouchi N, Higuchi A, Ohashi K, Oshima Y, Gokce N, Shibata R, Akasaki $Y$, Shimono A, Walsh K. Sfrp5 is an anti-inflammatory adipokine that modulates metabolic dysfunction in obesity. Science 2010; 329: 454-457

143 Dorresteijn JA, Visseren FL, Spiering W. Mechanisms linking obesity to hypertension. Obes Rev 2012; 13: 17-26

144 Harford KA, Reynolds CM, McGillicuddy FC, Roche HM. Fats, inflammation and insulin resistance: insights to the role of macrophage and T-cell accumulation in adipose tissue. Proc Nutr Soc 2011; 70: 408-417

145 Xu H, Barnes GT, Yang $Q$ Tan G, Yang D, Chou CJ, Sole J, Nichols A, Ross $J S$, Tartaglia LA, Chen $H$. Chronic inflammation in fat plays a crucial role in the development of obesity-related insulin resistance. J Clin Invest 2003; 112: 1821-1830

146 Bruun JM, Lihn AS, Pedersen SB, Richelsen B. Monocyte chemoattractant protein-1 release is higher in visceral than subcutaneous human adipose tissue (AT): implication of macrophages resident in the AT. J Clin Endocrinol Metab 2005; 90: 2282-2289

147 Faber DR, Moll FL, Vink A, van der WC, Kalkhoven E, Schipper HS, Hajer $G R$, Monajemi H, Visseren FL. Adipose tissue quantity and composition contribute to adipokine concentrations in the subclavian vein and the inferior mesenteric vein. Int J Obes (Lond) 2012; 36: 1078-1085

148 Youn BS, Bang SI, Kloting N, Park JW, Lee N, Oh JE, Pi KB, Lee TH, Ruschke $K$, Fasshauer M, Stumvoll M, Bluher M. Serum progranulin concentrations may be associated with macrophage infiltration into omental adipose tissue. Diabetes 2009; 58: 627-636.

149 Gannage-Yared MH, Khalife S, Semaan M, Fares F, Jambart S, Halaby G. Serum adiponectin and leptin levels in relation to the metabolic syndrome, androgenic profile and somatotropic axis in healthy nondiabetic elderly men. Eur J Endocrinol 2006; 155: 167-176

150 Gupta A, Gupta V, Agrawal S, Natu SM, Agrawal CG, Negi MP, Tiwari S. Association between circulating leptin and insulin resistance, the lipid profile, and metabolic risk factors in North Indian adult women. Biosci Trends 2010; 4: 325-332

151 Ingelsson E, Sundstrom J, Melhus H, Michaelsson K, Berne C, Vasan RS, Riserus $U$, Blomhoff $R$, Lind L, Arnlov J. Circulating retinol-binding protein 4, cardiovascular risk factors and prevalent cardiovascular disease in elderly. Atherosclerosis 2009; 206: 239-244

152 Li WC, Hsiao KY, Chen IC, Chang YC, Wang SH, Wu KH. Serum leptin is associated with cardiometabolic risk and predicts metabolic syndrome in Taiwanese adults. Cardiovasc Diabetol 2011; 10: 36

153 Lim S, Yoon JW, Choi SH, Park YJ, Lee JJ, Park JH, Lee SB, Kim KW, Lim JY, Kim YB, Park KS, Lee HK, Cho SI, Jang HC. Combined impact of adiponectin and retinol-binding protein 4 on metabolic syndrome in elderly people: the Korean Longitudinal Study on Health and Aging. Obesity (Silver Spring) 2010; 18: 826-832

154 Qi Q, Yu Z, Ye X, Zhao F, Huang P, Hu FB, Franco OH, Wang J, Li H, Liu $Y$, Lin $X$. Elevated retinol-binding protein 4 levels are associated with metabolic syndrome in Chinese people. J Clin Endocrinol Metab 2007; 92: 4827-4834

155 Shim CY, Park S, Kim JS, Shin DJ, Ko YG, Kang SM, Choi D, Ha JW, Jang $Y$, Chung N. Association of plasma retinol-binding protein 4, adiponectin, and high molecular weight adiponectin with insulin resistance in non-diabetic hypertensive patients. Yonsei Med J 2010; 51: 375-384

156 Ulgen F, Herder C, Kuhn MC, Willenberg HS, Schott M, Scherbaum WA Schinner S. Association of serum levels of retinol-binding protein 4 with male sex but not with insulin resistance in obese patients. Arch Physiol Biochem 2010; 116: 57-62

157 Wang J, Li H, Franco OH, Yu Z, Liu Y, Lin X. Adiponectin and metabolic syndrome in middle-aged and elderly Chinese. Obesity (Silver Spring) 2008; 16 : 172-178 
158 Wannamethee SG, Lowe GD, Rumley A, Cherry L, Whincup PH, Sattar N. Adipokines and risk of type 2 diabetes in older men. Diabetes Care 2007; 30: 1200-1205

159 Yun JE, Kimm H, Jo J, Jee SH. Serum leptin is associated with metabolic syndrome in obese and nonobese Korean populations. Metabolism 2010; 59: 424-429

160 Chen MP, Chung FM, Chang DM, Tsai JC, Huang HF, Shin SJ, Lee YJ. Elevated plasma level of visfatin/pre-B cell colony-enhancing factor in patients with type 2 diabetes mellitus. J Clin Endocrinol Metab 2006; 91: 295-299

161 Shaker O, El-Shehaby A, Zakaria A, Mostafa N, Talaat S, Katsiki N, Mikhailidis DP. Plasma visfatin and retinol binding protein-4 levels in patients with type 2 diabetes mellitus and their relationship to adiposity and fatty liver. Clin Biochem 2011; 44: 1457-1463

162 Alessi MC, Juhan-Vague I. PAI-1 and the metabolic syndrome: links, causes, and consequences. Arterioscler Thromb Vasc Biol 2006; 26: 2200-2207

163 Lawlor DA, Davey SG, Ebrahim S, Thompson C, Sattar N. Plasma adiponectin levels are associated with insulin resistance, but do not predict future risk of coronary heart disease in women. J Clin Endocrinol Metab 2005; 90: 5677-5683

164 Lawlor DA, Smith GD, Kelly A, Sattar N, Ebrahim S. Leptin and coronary heart disease risk: prospective case control study of British women. Obesity (Silver Spring) 2007; 15: 1694-1701

165 Sattar N, Wannamethee G, Sarwar N, Tchernova J, Cherry L, Wallace AM, Danesh J, Whincup PH. Adiponectin and coronary heart disease: a prospective study and meta-analysis. Circulation 2006; 114: 623-629

166 Sattar N, Wannamethee G, Sarwar N, Chernova J, Lawlor DA, Kelly A Wallace AM, Danesh J, Whincup PH. Leptin and coronary heart disease: prospective study and systematic review. J Am Coll Cardiol 2009; 53: 167-175

167 Soderberg S, Colquhoun D, Keech A, Yallop J, Barnes EH, Pollicino C, Simes J, Tonkin AM, Nestel P. Leptin, but not adiponectin, is a predictor of recurrent cardiovascular events in men: results from the LIPID study. Int J Obes (Lond) 2009; 33: 123-130

168 Frystyk J, Berne C, Berglund L, Jensevik K, Flyvbjerg A, Zethelius B. Serum adiponectin is a predictor of coronary heart disease: a population-based 10-year follow-up study in elderly men. J Clin Endocrinol Metab 2007; 92: 571-576

169 Lee SA, Kallianpur A, Xiang YB, Wen W, Cai Q, Liu D, Fazio S, Linton $M F$, Zheng $W$, Shu XO. Intra-individual variation of plasma adipokine levels and utility of single measurement of these biomarkers in population-based studies. Cancer Epidemiol Biomarkers Prev 2007; 16: $2464-2470$

170 Hill MJ, Kumar S, McTernan PG. Adipokines and the clinical laboratory: what to measure, when and how? J Clin Pathol 2009; 62: 206-211

171 Schipper HS, de JW, van Dijk ME, Meerding J, Zelissen PM, Adan RA Prakken BJ, Kalkhoven E. A multiplex immunoassay for human adipokine profiling. Clin Chem 2010; 56: 1320-1328

172 Amato MC, Giordano C, Galia M, Criscimanna A, Vitabile S, Midiri M, Galluzzo A. Visceral Adiposity Index: a reliable indicator of visceral fat function associated with cardiometabolic risk. Diabetes Care 2010; 33: 920-922

173 Amato MC, Pizzolanti G, Torregrossa V, Misiano G, Milano S, Giordano C. Visceral adiposity index (VAI) is predictive of an altered adipokine profile in patients with type 2 diabetes. PLoS One 2014; 9: e91969

174 Amato MC, Giordano C. Visceral adiposity index: an indicator of adipose tissue dysfunction. Int J Endocrinol. 2014730827

175 Lumeng CN, Bodzin JL, Saltiel AR. Obesity induces a phenotypic switch in adipose tissue macrophage polarization. J Clin Invest 2007; 117: 175-184
176 Nannipieri M, Bonotti A, Anselmino M, Cecchetti F, Madec S, Mancin E, Baldi S, Santini F, Pinchera A, Rossi M, Ferrannini E. Pattern of expression of adiponectin receptors in human adipose tissue depots and its relation to the metabolic state. Int J Obes (Lond) 2007; 31 : 1843-1848

177 Motoshima H, Wu X, Sinha MK, Hardy VE, Rosato EL, Barbot DJ, Rosato $F E$, Goldstein BJ. Differential regulation of adiponectin secretion from cultured human omental and subcutaneous adipocytes: effects of insulin and rosiglitazone. J Clin Endocrinol Metab 2002; 87: 56625667

178 Miranda M, Escote X, Ceperuelo-Mallafre V, Alcaide MJ, Simon I, Vilarrasa $N$, Wabitsch $M$, Vendrell J. Paired subcutaneous and visceral adipose tissue aquaporin-7 expression in human obesity and type 2 diabetes: differences and similarities between depots. J Clin Endocrinol Metab 2010; 95: 3470-3479

179 Le KA, Mahurkar S, Alderete TL, Hasson RE, Adam TC, Kim JS, Beale E, Xie C, Greenberg AS, Allayee H, Goran MI. Subcutaneous adipose tissue macrophage infiltration is associated with hepatic and visceral fat deposition, hyperinsulinemia, and stimulation of NF-kappaB stress pathway. Diabetes 2011; 60: 2802-2809

180 Bakker AH, Nijhuis J, Buurman WA, van Dielen FM, Greve JW. Low number of omental preadipocytes with high leptin and low adiponectin secretion is associated with high fasting plasma glucose levels in obese subjects. Diabetes Obes Metab 2006; 8: 585-588

181 Hirata $Y$, Tabata M, Kurobe H, Motoki T, Akaike M, Nishio C, Higashida M, Mikasa H, Nakaya Y, Takanashi S, Igarashi T, Kitagawa T, Sata M. Coronary atherosclerosis is associated with macrophage polarization in epicardial adipose tissue. J Am Coll Cardiol 2011; 58: 248-255

182 Hirata Y, Kurobe H, Akaike M, Chikugo F, Hori T, Bando Y, Nishio C, Higashida M, Nakaya Y, Kitagawa T, Sata M. Enhanced inflammation in epicardial fat in patients with coronary artery disease. Int Heart J 2011; 52: 139-142

183 Garaulet M, Viguerie N, Porubsky S, Klimcakova E, Clement K, Langin $D$, Stich $V$. Adiponectin gene expression and plasma values in obese women during very-low-calorie diet. Relationship with cardiovascular risk factors and insulin resistance. J Clin Endocrinol Metab 2004; 89: 756-760

184 Garcia de la TN, Rubio MA, Bordiu E, Cabrerizo L, Aparicio E, Hernandez C, Sanchez-Pernaute A, ez-Valladares L, Torres AJ, Puente M, Charro AL. Effects of weight loss after bariatric surgery for morbid obesity on vascular endothelial growth factor-A, adipocytokines, and insulin. J Clin Endocrinol Metab 2008; 93: 4276-4281

185 Moschen AR, Molnar C, Geiger S, Graziadei I, Ebenbichler CF, Weiss H Kaser S, Kaser A, Tilg H. Anti-inflammatory effects of excessive weight loss: potent suppression of adipose interleukin 6 and tumour necrosis factor alpha expression. Gut 2010; 59: 1259-1264

186 Cancello $R$, Henegar C, Viguerie N, Taleb S, Poitou C, Rouault C, Coupaye M, Pelloux V, Hugol D, Bouillot JL, Bouloumie A, Barbatelli G, Cinti S, Svensson PA, Barsh GS, Zucker JD, Basdevant A, Langin D, Clement $K$ Reduction of macrophage infiltration and chemoattractant gene expression changes in white adipose tissue of morbidly obese subjects after surgery-induced weight loss. Diabetes 2005; 54: 22772286

187 Clement K, Viguerie N, Poitou C, Carette C, Pelloux V, Curat CA, Sicard A, Rome S, Benis A, Zucker JD, Vidal H, Laville M, Barsh GS, Basdevant $A$, Stich $V$, Cancello $R$, Langin $D$. Weight loss regulates inflammationrelated genes in white adipose tissue of obese subjects. FASEB J 2004 ; 18: 1657-1669

188 Zhang H, Wang Y, Zhang J, Potter BJ, Sowers JR, Zhang C. Bariatric surgery reduces visceral adipose inflammation and improves endothelial function in type 2 diabetic mice. Arterioscler Thromb Vasc Biol 2011; 31: 2063-2069 